\title{
Current Diagnosis, Treatment and Clinical Challenges in the Management of Lipodystrophy Syndromes in Children and Young People
}

\author{
(1) Samim Özen ${ }^{1}$, (1) Barış Akıncı²,3, (1) Elif A. Oral3 \\ ${ }^{1}$ Ege University Faculty of Medicine, Department of Pediatric Endocrinology, Izmir, Turkey \\ ${ }^{2}$ Dokuz Eylül University Faculty of Medicine, Department of Internal Medicine, Division of Endocrinology and Metabolism, Izmir, Turkey \\ 3University of Michigan Medical School, Department of Medicine, and Brehm Center for Diabetes, Division of Metabolism, Endocrinology, and \\ Diabetes, Michigan, USA
}

\begin{abstract}
Lipodystrophy is a heterogeneous group of disorders characterized by lack of body fat in characteristic patterns, which can be genetic or acquired. Lipodystrophy is associated with insulin resistance that can develop in childhood and adolescence, and usually leads to severe metabolic complications. Diabetes mellitus, hypertriglyceridemia, and hepatic steatosis ordinarily develop in these patients, and most girls suffer from menstrual abnormalities. Severe complications develop at a relatively young age, which include episodes of acute pancreatitis, renal failure, cirrhosis, and complex cardiovascular diseases, and all of these are associated with serious morbidity. Treatment of lipodystrophy consists of medical nutritional therapy, exercise, and the use of anti-hyperglycemic and lipid-lowering agents. New treatment modalities, such as metreleptin replacement, promise much in the treatment of metabolic abnormalities secondary to lipodystrophy. Current challenges in the management of lipodystrophy in children and adolescents include, but are not limited to: (1) establishing specialized centers with experience in providing care for lipodystrophy presenting in childhood and adolescence; (2) optimizing algorithms that can provide some guidance for the use of standard and novel therapies to ensure adequate metabolic control and to prevent complications; (3) educating patients and their parents about lipodystrophy management; (4) improving patient adherence to chronic therapies; (5) reducing barriers to access to novel treatments; and (5) improving the quality of life of these patients and their families.
\end{abstract}

Keywords: Lipodystrophy, childhood, adolescence, progeria, metreleptin

\section{Introduction}

Lipodystrophy is the general term for a heterogeneous group of disorders characterized by near total [generalized lipodystrophy (GL)] or partial [partial lipodystrophy (PL)] lack of body fat (1). Lipodystrophy can be genetic or acquired. Congenital GL (CGL), familial PL (FPLD), acquired GL (AGL), and acquired PL (APL) make up the four major categories of lipodystrophy in clinical practice, although there are several others such as progeria associated lipodystrophy, auto-inflammatory syndromes, and complex syndromes associated with lipodystrophy $(1,2,3,4,5)$. The current classification schema, which is based on clinical presentation, may change as our understanding of the disease processes improve. In this paper, we will focus on presentation of various forms of lipodystrophy during childhood and adolescence and then review the general clinical approach for these patients.

\section{Types of Lipodystrophy in Children and Young People}

\section{Genetic Lipodystrophy Syndromes \\ Congenital Generalized Lipodystrophy}

CGL (Berardinelli-Seip syndrome) is the most common lipodystrophy subtype in infancy and early childhood, while the incidence of FPLD increases close to puberty $(3,4,5,6)$. CGL cases made up almost half (519 of 1141) of pediatric patients with non-human immunodeficiency 
virus lipodystrophy identified by a recent systematic review of a total of 351 studies (6). CGL is a rare disorder with autosomal recessive inheritance, in which patients are born with near total lack of body fat. These patients have a remarkable phenotype characterized by near total absence of adipose tissue, muscular overdevelopment and prominent subcutaneous veins, which can be noticed either at birth or in the first year of life (7). The prevalence of CGL is uncertain, but it has been estimated at approximately $1: 10$ million (8). A recent study reported an estimated prevalence of 0.23 cases/million for diagnosed GL (9). However, CGL has a higher prevalence in certain parts of the world as a result of consanguineous marriages. We reported an estimated CGL prevalence of 1:2 million in Turkey, considerably higher than in other reports but still quite rare (10).

There are four major subtypes of CGL based on mechanism:

CGL1 [Online Mendelian Inheritance in Man (OMIM) \#608594] is caused by pathogenic variants of the 1 acylglycerol 3-phosphate acyltransferase $\beta 2$ (AGPAT2) gene (11). The AGPAT2 enzyme converts lysophosphatidic acid into phosphatidic acid, a critical step in triglyceride synthesis (12). Homozygous pathogenic variants that eliminate enzyme activity have been demonstrated in the majority of CGL1 cases. Compound heterozygous or homozygous pathogenic variants with low levels of in vitro enzyme activity have also been reported $(7,13)$. Although patients with CGL1 lack metabolically active adipose tissue, the preservation of residual mechanical adipose tissue in the palms, soles, scalp, orbital and periarticular regions and the perineum is clinically apparent $(14,15)$.

CGL2 (OMIM \#269700) is caused by pathogenic variants of the Berardinelli-Seip congenital lipodystrophy 2 (BSCL2) gene (16), which encodes the transmembrane protein seipin. This protein is involved in the fusion of small lipid droplets in adipocytes, as well as in the differentiation of adipocytes (17). The majority of identified variants have been classified as null pathogenic variants, based on functional investigations, which lead to severe disruption of the protein. Missense pathogenic variants have also been reported $(7,13,18)$.

Pathogenic variants of the caveolin 1 (CAV1) gene, which encodes caveolin 1, a principal component of the caveolae, causes CGL3 (OMIM \#612526). A homozygous nonsense pathogenic variant in CAV1 was reported in a patient with CGL from Brazil (19). Magnetic resonance imaging of the proband confirmed the absence of metabolically active adipose tissue, while bone marrow adipose tissue was preserved (19). Heterozygous CAV1 pathogenic variants have also been associated with PL (20).
CGL4 (OMIM \#613327) is caused by homozygous or compound heterozygous pathogenic variants in the polymerase 1 and transcript release factor (PTRF, or cavin-1) gene (21). PTRF regulates the expression of caveolins 1 and 3. Cavin-1 plays a major role in the formation of caveolae and caveolin stabilization through interaction with the cellular cytoskeleton. Cavin-1 regulates adipocyte differentiation and it is a determining factor in the capacity of adipose tissue to expand (22). CGL3 and CGL4 have distinct clinical characteristics (Table 1) $(23,24,25)$.

In addition to these four major groups of CGL, patients with GL associated with Lamin A/C (LMNA) p.T10I (26), and biallelic peroxisome proliferator activated receptor gamma $(P P A R G)$ (27) pathogenic variants have been reported. Patients with biallelic loss-of-function pathogenic variants in phosphate cytidylyltransferase 1 alpha (PCYT1A) gene were reported to have a severe PL phenotype (28), and potentially can be classified in the CGL category.

Table 1 summarizes subtypes of CGL.

\section{Familial Partial Lipodystrophy}

FPLD is a subtype of lipodystrophy with a genetic background, which in adults is more common than any other subtype of lipodystrophy $(4,8,9,29)$. FPLD exhibits a typical fat tissue distribution. Phenotypic features are more prominent in females. Loss of adipose tissue is predominantly observed in the upper and lower extremities. Patients may exhibit accumulation of fat in certain areas such as the face and neck, and perineal and intra-abdominal depots $(2,4,30,31,32)$. A Cushingoid-appearance can be observed, due to thin limbs, facial fat accumulation and increased fat in the dorsocervical region resembling a 'buffalo hump' (5). The partial loss of fat may be apparent in early life, but typically becomes more pronounced over time in FPLD, and most patients start to lose adipose tissue after puberty (30). For this reason, it is difficult to recognize these patients in childhood. However, a few patients with FPLD have been reported from pediatric endocrinology practices (6).

Most FPLD subtypes are inherited in an autosomal dominant (AD) manner. However, recent evidence suggests that a large group of patients with FPLD1, also known as Koberlingtype FPLD (OMIM \#608600), follow a polygenic inheritance pattern $(33,34,35)$. FPLD2, the Dunnigan variety, (OMIM \#151660), is caused by AD pathogenic variants in the LMNA gene (36), which encodes nuclear lamins $A$ and $C(36,37)$. LMNA R482W and R482Q are the most common pathogenic variants (38,39). FPLD3 (OMIM \#604367) is caused by $\mathrm{AD}$ pathogenic variants in the peroxisome proliferator- 
activated receptor gamma gene $(P P A R G)$ on chromosome 3 p25 $(40,41)$. PPARG plays a major role in the regulation of adiposity differentiation (40). Other subtypes of FPLD are rare. A recent review of these subtypes is available (1). The subtypes of FPLD are presented in Table 2.

\section{Acquired Lipodystrophy Syndromes}

\section{Acquired Generalized Lipodystrophy, Lawrence Syndrome}

AGL affects the whole body and causes generalized fat loss. Patients develop typical metabolic complications of lipodystrophy including severe insulin resistance, diabetes, hypertriglyceridemia and non-alcoholic steatohepatitis (NASH) (42). The clinical phenotype is very similar to that of CGL. However, patients with AGL are born with normal fat tissue. Loss of adipose tissue typically begins in childhood or adolescence. Marked phenotypic features occur over differing lengths of time, from a few weeks to a year. The cause of the disease is still unknown. The disease coincides with other autoimmune diseases such as juvenile dermatomyositis, type 1 diabetes and autoimmune hepatitis. AGL is associated with panniculitis in some patients. Complement abnormalities may also be present $(8,42,43)$.

\section{Acquired Partial Lipodystrophy, Barraquer-Simons Syndrome}

APL (OMIM \#608709) is characterized by the loss of fat from the face, neck, arms, chest and abdomen with preservation of lower extremity fat. Clinical onset typically occurs in childhood or adolescence and females predominate at a ratio of $4: 1$. Loss of fat first manifests in the face, and gradually progresses to the upper extremities, thorax and upper abdomen, symmetrically and in a cephalocaudal fashion. Excessive deposition of fat may be observed in the lower limbs (44). The etiology of APL remains unknown, however, there is a link to autoimmune abnormalities and coincidental autoimmune conditions can be observed. APL is associated with low complement factor 3 (C3) levels and membranoproliferative glomerulonephritis in some patients, which may cause end stage renal disease in some

\begin{tabular}{|c|c|c|c|}
\hline Subtype & Gene & Molecular basis & Phenotype \\
\hline CGL1 & AGPAT2 & $\begin{array}{l}\text { AGPAT2 plays a major role in the metabolism } \\
\text { of lysophosphatidic acid, a potent signaling } \\
\text { molecule responsible for activating a G-protein- } \\
\text { linked receptor }\end{array}$ & $\begin{array}{l}\text { Near total fat loss, preserved mechanical fat, severe } \\
\text { insulin resistance, metabolic abnormalities, cystic } \\
\text { lesions in long bones }\end{array}$ \\
\hline CGL2 & BSCL2 & $\begin{array}{l}\text { Seipin, encoded by BSCL2, plays a key role in the } \\
\text { fusion of small lipid droplets in the adipocytes } \\
\text { and in adipocyte differentiation }\end{array}$ & $\begin{array}{l}\text { Severe near total fat loss, almost no mechanical fat, } \\
\text { severe insulin resistance, metabolic abnormalities } \\
\text { and occasionally cystic lesions in long bones. May } \\
\text { be associated with delayed mental development and } \\
\text { cardiomyopathy }\end{array}$ \\
\hline CGL3 & $C A V 1$ & $\begin{array}{l}\text { Caveolin } 1 \text { is an integral component of caveolae, } \\
\text { which are present on adipocyte membranes. } \\
\text { Caveolae translocate fatty acids and other lipids } \\
\text { to lipid droplets }\end{array}$ & $\begin{array}{l}\text { Near total fat loss, preserved bone marrow fat, severe } \\
\text { insulin resistance, metabolic abnormalities, delayed } \\
\text { growth, short stature, hypocalcemia, vitamin D } \\
\text { resistance, and osteopenia }\end{array}$ \\
\hline \multirow{2}{*}{ CGL4 } & $\begin{array}{l}\text { LMNA } \\
\text { p.T10I }\end{array}$ & $\begin{array}{l}\text { LMNA codes nuclear envelope proteins, lamin } \\
\text { A and C. Mutant lamins disrupt the interaction } \\
\text { between the nuclear lamina and chromatin and } \\
\text { may result in apoptosis, which may be followed } \\
\text { by premature adipocyte death }\end{array}$ & $\begin{array}{l}\text { Near total loss of fat developing in early childhood, } \\
\text { severe insulin resistance, metabolic abnormalities, and } \\
\text { progeroid features }\end{array}$ \\
\hline & $\begin{array}{l}\text { LMNA } \\
\text { (Lamin } \\
\text { C-specific) }\end{array}$ & $\begin{array}{l}\text { Mutant lamin C may disrupt its interaction with } \\
\text { other cellular proteins resulting in defective } \\
\text { development and maintenance of adipose tissue }\end{array}$ & $\begin{array}{l}\text { Juvenile-onset generalized fat loss, severe insulin } \\
\text { resistance, metabolic abnormalities, phenotype very } \\
\text { similar to CGL1 }\end{array}$ \\
\hline
\end{tabular}


patients $(44,45,46)$. Drusen deposition in the macula has also been reported.

\section{Progeroid Disorders and Other Rare Genetic Lipodystrophy Syndromes}

Lipodystrophy is a part of the clinical picture in many progeroid syndromes $(1,47,48)$. There are also several other complex syndromes associated with lipodystrophy
(1). The characteristics of these syndromes are presented in Table 3.

\section{Other Causes of Acquired Lipodystrophy}

The development of lipodystrophy after whole body irradiation in preparation for bone marrow transplant $(49,50,51,52,53,54)$, following cranial irradiation and as a result of hypothalamic tumors (55) has been described

\begin{tabular}{|c|c|c|}
\hline Subtype & Gene & Molecular basis \\
\hline $\begin{array}{l}\text { FPLD1 } \\
\text { (Koberling } \\
\text { type) }\end{array}$ & Unknown & Polygenic etiology? \\
\hline $\begin{array}{l}\text { FPLD2 } \\
\text { (Dunnigan } \\
\text { type) }\end{array}$ & $L M N A$ & $\begin{array}{l}\text { LMNA codes nuclear lamina proteins, lamin A and } \\
\text { C. Mutant lamins disrupt the interaction between } \\
\text { the nuclear lamina and chromatin and may result } \\
\text { in apoptosis, which may be followed by premature } \\
\text { adipocyte death }\end{array}$ \\
\hline FPLD3 & PPARG & $\begin{array}{l}P P A R G \text { plays a major role in the regulation of } \\
\text { adiposity differentiation }\end{array}$ \\
\hline FPLD4 & PLIN1 & $\begin{array}{l}\text { Perilipin coats lipid droplet and its required for } \\
\text { optimal lipid incorporation and release from } \\
\text { droplet }\end{array}$ \\
\hline FPLD5 & CIDEC & $\begin{array}{l}\text { CIDEC is expressed in lipid droplets. Pathogenic } \\
\text { variants of the CIDEC gene may result in the loss } \\
\text { of ability of lipid droplets to store fat and defects in } \\
\text { adipocyte differentiation }\end{array}$ \\
\hline
\end{tabular}

Lipodystrophy syndromes associated with lipomatosis

FPLD6 LIPE

MFN2

\section{Other FPLD syndromes}

ADRA2A

AKT2

CAV1

(heterozygous)

PCYT1A

(biallelic)
LIPE encodes hormone-sensitive lipase, involved in lipolysis regulation

MFN2 gene encodes mitofusin 2, a membranebound mediator of mitochondrial membrane fusion and inter-organelle communication

ADRA2A activation inhibits CAMP production and reduces lipolysis

AKT is a serine/threonine protein kinase involved in insulin-stimulated glucose transport

CAV1 is an integral component of caveolae, which are present on adipocyte membranes. Caveolae translocate fatty acids and other lipids to lipid droplets

Rate-limiting enzyme in the Kennedy pathway of de novo phosphatidylcholine synthesis

\section{Phenotype}

Fat loss mainly limited to extremities, truncal obesity, palpable "ledge" between lipodystrophic and non-lipodystrophic areas, severe insulin resistance, and metabolic abnormalities

Fat loss dominantly affects the limbs, increased muscularity, excess fat in the face and neck, labial pseudohypertrophy, increased mon pubis fat, severe insulin resistance and metabolic abnormalities

Milder fat loss mostly affects the distal limbs, no accumulation of adipose tissue in the face and neck, severe insulin resistance and metabolic abnormalities

Fat loss in the lower limbs and femorogluteal depot, severe insulin resistance, and metabolic abnormalities.

Partial lipodystrophy, acanthosis nigricans, severe insulin resistance, metabolic abnormalities, and diabetic ketoacidosis

Late-onset partial fat loss affecting the lower limbs, multiple lipomatosis, and progressive distal symmetric myopathy

Partial lipodystrophy with upper body adipose hyperplasia (lipomatosis without encapsulation), and low leptin levels

FPLD phenotype, increased muscularity, needs to be confirmed in further pedigrees

Partial fat loss affecting the limbs, severe insulin resistance, and metabolic abnormalities

Partial fat loss from the upper body with preservation of fat in the lower body, neurodegeneration, cerebellar ataxia, congenital cataracts and neurosensory deafness

Severe lipodystrophy with near total lack of subcutaneous fat in the arms, legs, and buttocks. Preservation of fat in the trunk, in the dorsocervical and submandibular regions, and over the mons pubis. Severe insulin resistance, and metabolic abnormalities, potentially can be classified in the CGL category

ADRA2A: adrenoceptor $\alpha-2 \mathrm{~A}, A K T 2$ : AKT serine/threonine kinase 2, CAV1: caveolin 1, CIDEC: cell death inducing DFFA like effector C, FPLD: familial partial lipodystrophy, LIPE: hormone sensitive type lipase E, LMNA: lamin A/C, MFN2: mitofusin 2, PCYT1A: phosphate cytidylyltransferase 1 alpha, PLIN1: perilipin 1, PPARG: peroxisome proliferator-activated receptor gamma 
and is a clinically neglected cause of lipodystrophy. When children have aggressive treatments for childhood cancers, they should be assessed for signs of fat loss and ensuing metabolic abnormalities. In a young child presenting with lipodystrophy, it is very important to consider the possibility of central nervous system tumors, especially when the clinical presentation does not fit with AGL. Other forms of cancer therapy, such as checkpoint inhibitors, may lead to

\begin{tabular}{|c|c|c|c|}
\hline Disorder/Syndrome & Gene & Lipodystrophy pattern & Clinical features \\
\hline $\begin{array}{l}\text { Hutchinson-Gilford progeria } \\
\text { syndrome }\end{array}$ & LMNA & $\begin{array}{l}\text { Severe partial lipodystrophy } \\
\text { which may progress to an almost } \\
\text { complete absence of subcutaneous } \\
\text { fat }\end{array}$ & $\begin{array}{l}\text { Short stature, low body weight, and progeroid } \\
\text { features }\end{array}$ \\
\hline Atypical progeroid syndrome & LMNA & $\begin{array}{l}\text { Fat loss more extensive than the } \\
\text { typical pattern in FPLD2 }\end{array}$ & $\begin{array}{l}\text { Muscular symptoms, skin defects, } \\
\text { cardiomyopathy and rhythm abnormalities, and } \\
\text { progeroid features }\end{array}$ \\
\hline MADA & $L M N A$ & $\begin{array}{l}\text { Partial loss of subcutaneous fat } \\
\text { from the extremities along with } \\
\text { normal or excessive fat in the face } \\
\text { and the neck }\end{array}$ & $\begin{array}{l}\text { Craniofacial, skeletal and cutaneous } \\
\text { abnormalities }\end{array}$ \\
\hline MADB & ZMPSTE24 & $\begin{array}{l}\text { More generalized loss of } \\
\text { subcutaneous fat than MADA }\end{array}$ & $\begin{array}{l}\text { Mandibular and clavicular hypoplasia, } \\
\text { acroosteolysis, premature renal failure, and } \\
\text { progeroid features }\end{array}$ \\
\hline JMP syndrome & PSMB8 & Panniculitis-induced lipodystrophy & $\begin{array}{l}\text { Autoinflammatory syndrome, joint contractures, } \\
\text { muscle atrophy, and microcytic anemia }\end{array}$ \\
\hline CANDLE syndrome & PSMB8 & $\begin{array}{l}\text { Partial loss of adipose tissue from } \\
\text { the upper limbs and face }\end{array}$ & $\begin{array}{l}\text { Autoinflammatory syndrome, chronic atypical } \\
\text { neutrophilic dermatitis, and recurrent fever }\end{array}$ \\
\hline SHORT syndrome & PIK3R1 & Variable loss of subcutaneous fat & $\begin{array}{l}\text { Short stature, hyperextensibility, ocular } \\
\text { depression, teething delay }\end{array}$ \\
\hline $\begin{array}{l}\text { Néstor-Guillermo progeria } \\
\text { syndrome }\end{array}$ & BANF1 & Decreased subcutaneous fat & $\begin{array}{l}\text { Progeroid features, growth retardation, thin } \\
\text { limbs, and stiff joints }\end{array}$ \\
\hline Neonatal progeroid syndrome & CAV1 & Generalized loss of body fat & Progeroid appearance at birth \\
\hline $\begin{array}{l}\text { Neonatal Marfan progeroid } \\
\text { syndrome }\end{array}$ & FBN1 & Generalized loss of fat & $\begin{array}{l}\text { Progeroid appearance, Marfanoid habitus, } \\
\text { skeletal features, dilated aortic bulb, bilateral } \\
\text { subluxation of the lens, myopia, no significant } \\
\text { metabolic abnormality associated with insulin } \\
\text { resistance }\end{array}$ \\
\hline Bloom syndrome & $B L M$ & $\begin{array}{l}\text { Paucity of adipose tissue and low } \\
\text { BMI }\end{array}$ & $\begin{array}{l}\text { Short stature, sun-sensitive, telangiectasia, and } \\
\text { risk of cancers }\end{array}$ \\
\hline Cockayne syndrome & $\begin{array}{l}\text { ERCC6, } \\
\text { ERCC8 }\end{array}$ & Generalized loss of fat & $\begin{array}{l}\text { Short stature, mental retardation, chorioretinitis, } \\
\text { and progeroid features }\end{array}$ \\
\hline \multirow[t]{3}{*}{ AREDYLD syndrome } & Unknown & Generalized loss of fat & $\begin{array}{l}\text { Acrorenal field defect, ectodermal dysplasia, and } \\
\text { multiple abnormalities }\end{array}$ \\
\hline & SPRTN & Lipodystrophy & Progeroid features, hepatocellular carcinoma \\
\hline & OPA3 & Lipodystrophy & $\begin{array}{l}\text { Optic atrophy, cataracts, and peripheral } \\
\text { neuropathy }\end{array}$ \\
\hline
\end{tabular}

BANF1: barrier to autointegration factor 1, BLM: bloom syndrome RecQ helicase-like, CAV1: caveolin 1, ERCC6: excision repair cross-complementing group 6, ERCC8: excision repair cross-complementing group 8, FBN1: fibrillin-1, KCNJ6: potassium inwardly-rectifying channel subfamily J member 6, LMNA: lamin A/C, OPA3: optic atrophy 3, PIK3R1: phosphatidylinositol 3-kinase, regulatory subunit 1, POLD1: DNA polymerase delta 1, catalytic subunit, PSMB8: proteasome subunit beta-type 8, SPRTN: spartan, WRN: Werner syndrome RecQ like helicase, ZMPSTE24: Zinc metallopeptidase STE24, BMI: body mass index, MADA: mandibulo-acral dysplasia type A, MADB: mandibulo-acral dysplasia type B, FPLD2: familial partial lipodystrophy type 2 
fat loss to varying extents $(56,57)$. These unusual forms of acquired lipodystrophy will be reviewed in a specific review in the near future.

\section{Clinical Features of Lipodystrophy}

\section{Leptin Levels}

GL is characterized by very low or undetectable levels of leptin. However, in PL leptin concentrations may range from low to normal (58). Several studies have suggested that baseline serum leptin measurement may assist physicians to identify PL patients who are more likely to benefit from leptin replacement $(59,60)$. Leptin concentrations correlate with fat mass, and females have higher leptin concentrations than men in adulthood (61). However, it is challenging to interpret leptin levels in infancy, childhood and adolescence. Girls generally have higher leptin levels after the completion of puberty, as might be expected given the difference in concentrations seen in adults of different genders $(62,63)$. Prepubertal levels of leptin are similar in both sexes, although concentrations fluctuate during infancy $(62,64)$. Younger infants have higher leptin levels than older infants presumably secondary to an initial increase in breast milk leptin from colostrum to mature milk, which is followed by a decreasing trend during the first months of lactation and a subsequent increase during the late period of lactation $(65,66,67)$. Leptin concentrations correlate with age in prepubertal girls and boys and increase in both boys and girls during early puberty. In boys, this early pubertal leptin peak is followed by a decrease in leptin concentrations several years after the rise in serum testosterone levels. However, in girls, leptin concentrations continue to increase during puberty in parallel with increasing levels of estrogen. The concentration of leptin peaks in mid-puberty and maintains this plateau level thereafter (62). Thus, clinicians should pay attention to many factors when interpreting leptin concentrations. Serum leptin measurement may help clinicians with the management of lipodystrophy, but it should not be considered as a reliable tool to diagnose or rule out lipodystrophy. In addition to leptin, adiponectin concentrations are helpful in certain patients. A relatively high concentration of adiponectin is a distinguished characteristic of CGL2, although serum leptin is extremely low in all subtypes of CGL $(10,68)$.

\section{Metabolic Abnormalities}

Patients with lipodystrophy may develop metabolic abnormalities associated with insulin resistance before adulthood, which are more severe and have an earlier onset in GL $(3,31,43,69)$. These metabolic abnormalities include, but are not limited to, diabetes, hypertriglyceridemia, hepatic steatosis, and NASH (3). Most females with lipodystrophy suffer from polycystic ovary syndrome (PCOS). Some of the factors determining the severity of metabolic abnormalities are the degree of adipose tissue loss, type of lipodystrophy, age, and sex. However, the severity of metabolic abnormalities may vary even among subjects with the same genetic pathogenic variant $(30,32,70,71)$.

Hyperphagia usually develops due to severe leptin deficiency in early childhood in subjects with CGL (7). Accelerated linear growth, advanced bone age and signs indicative of acromegaly, such as enlargement of the hands, feet and jaw, may be observed (3). Cystic bone lesions are frequently noted in CGL1 patients $(10,72,73)$. Hyperinsulinemia and severe insulin resistance develop in the majority of patients with CGL due to near total adipose tissue loss and leptin deficiency $(10,74)$. Acanthosis nigricans (AN), a clinical marker of insulin resistance, can be observed in body folds such as the axilla and neck during childhood, with a strong likelihood of a further increase after puberty $(3,8)$. Approximately $45 \%$ of patients with CGL develop diabetes mellitus before puberty $(7,10)$. The treatment of diabetes is challenging, and high-doses of insulin ( $>100$ units/day) may be required. Although most patients are poorly controlled, diabetic ketoacidosis rarely develops, but has been reported, probably as a result of severe hyperinsulinemia and lack of fat tissue (4). Hypertriglyceridemia usually develops in childhood. Eruptive xanthomas and recurrent episodes of pancreatitis caused by severe hypertriglyceridemia may emerge after puberty (3). Hepatic disease is more aggressive in patients with CGL2 (10). Hepatomegaly is remarkable at very young ages $(3,10)$. Patients may develop cirrhosis during childhood (10). PCOS, hyperandrogenism, and menstrual irregularity are common in adolescent girls (75).

AN, metabolic abnormalities associated with insulin resistance and hepatic steatosis may be observed in young people with FPLD (31), albeit milder in presentation than in CGL. Hypertriglyceridemia is common and can be severe. Episodes of acute pancreatitis may be observed. Cardiomyopathy and myopathy, as well as features resembling muscular dystrophy, may be detected in patients with FPLD2 $(8,31,59)$. In contrast to other forms of lipodystrophy, in APL metabolic complications have rarely been reported (44). However, our previous observations suggested that a subgroup of patients with APL developed metabolic abnormalities associated with insulin resistance, which can also be progressive in some cases. Although the majority of these patients were adults, a few of them developed metabolic abnormalities in their younger years (46). 


\section{Treatment of Lipodystrophy in Children and Young People}

\section{General Guidelines}

Although there is no curative treatment for lipodystrophy syndromes, early diagnosis of these patients may prevent mortality or serious morbidity. The aim of medical treatment is to correct metabolic abnormalities associated with lipodystrophy and prevent end-organ complications. Medical nutrition therapy (MNT) and exercise are important tools in the management of patients with lipodystrophy, although it is not easy for patients and families to comply with these therapies. Hyperphagia due to leptin deficiency is a serious problem in these children. However, weight increase is only part of the clinical problem. Since overeating exacerbates hepatic steatosis, diabetes and hyperlipidemia, particularly in babies and children, dietary fat intake should be reduced, and fat should be predominantly taken in the form of cismonounsaturated fats and long chain omega-3 fatty acids. Medium chain triglycerides in infant formulas may be helpful to reduce triglyceride levels. In patients developing acute pancreatitis secondary to hypertriglyceridemia the amount of dietary fat should be severely restricted. Patients with diabetes also have to balance their intake of carbohydrates (4). Exercise may improve metabolic parameters in patients with lipodystrophy. Sedentary time should be reduced as much as possible, with a focus on minimizing time spent on computer and television. Physical activity should be advised, unless contraindicated, and a detailed cardiac examination should be performed before advising an exercise plan. Special attention should be given to patients with CGL4, FPLD2 and progeroid syndromes. CGL patients with lytic bone lesions and also patients with hepatosplenomegaly should avoid contact sports $(1,4)$.

The use of lipid lowering drugs should be considered in children and adolescents with lipodystrophy when diet and exercise fail to control triglyceride levels. Fibrates are commonly used in children with very high triglyceride levels who are at risk for pancreatitis (76). Omega-3 fish oil therapy may also help to reduce triglyceride levels $(76,77)$. Although fibrates, alone and in combination with statins, have been shown to effectively reduce triglyceride levels in adults, data are very sparse in children $(6,77)$. Physicians should pay attention to safety measures while using fibrates for hypertriglyceridemia in children. Liver enzymes should be monitored. The risk of rhabdomyolysis should be kept in mind.

Metformin is the first choice to treat insulin resistant diabetes in children, in addition to MNT and lifestyle modification. The American Food and Drug Administration (FDA) approved the use of metformin for pediatric patients 10 years of age or older, noting that the safety and effectiveness of metformin have been shown in pediatric patients ages 10 to 16 years (78). Lipodystrophy patients with diabetes usually require insulin injections in combination with metformin (6). Insulin doses required to cause an effect may need to be very high, and patients may need to use concentrated forms of insulin (4).

Most patients with lipodystrophy desire a better cosmetic appearance. Patients with lipodystrophy may consider having cosmetic surgery, which may help them feel better about their physical appearance and may offer an improved quality of life. Excess unwanted localized fat can be removed from several locations that include the chin, buffalo hump, and vulvar region by liposuction or surgical excision. Lipoatrophic areas may also benefit from autologous adipose tissue transplantation, facial reconstruction and implants (1).

\section{Metreleptin Therapy}

Recombinant human leptin (metreleptin) therapy can be used to minimize and prevent complications of lipodystrophy (79). Severe hypoleptinemia causes hyperphagia and exacerbates metabolic complications associated with insulin resistance in patients with lipodystrophy (80). Several longterm studies have shown beneficial effects of metreleptin in GL with severely low serum leptin levels $(81,82,83,84)$. Metreleptin therapy has been associated with a significant reduction in triglyceride and hemoglobin A1 c (HbA1c) levels, and improvements in appetite control, insulin sensitivity and hepatic steatosis $(82,85,86,87,88,89)$.

The metabolic effects of metreleptin are remarkable in pediatric patients with lipodystrophy. In the largest report of the efficacy of metreleptin in pediatric patients with lipodystrophy to date, Brown et al (85) showed a reduction of HbA1c from a mean level of $8.3 \%$ to $6.5 \%$. Triglyceride levels significantly decreased from $374 \mathrm{mg} / \mathrm{dL}$ to $189 \mathrm{mg} /$ $\mathrm{dL}$. The benefit was more prominent in adolescents (from $9.6 \%$ to $7.1 \%$ for $\mathrm{HbA} 1 \mathrm{c}$, and from $556 \mathrm{mg} / \mathrm{dL}$ to $226 \mathrm{mg} /$ $\mathrm{dL}$ for triglycerides), presumably because of the presence of a more severe disease at baseline. Insulin sensitivity improved, and half of the patients who were on insulin at baseline were able to discontinue insulin treatment after metreleptin. The levels of liver enzymes decreased, and liver histology improved in a subset of patients who underwent before and after treatment liver biopsies. Metreleptin therapy was also associated with partial normalization of rapid growth in CGL, and improvements in pubertal development. The average dose of metreleptin was 0.082 
$\mathrm{mg} / \mathrm{kg} /$ day (range: 0.04 to $0.19 \mathrm{mg} / \mathrm{kg} /$ day; absolute dose: $4.1 \mathrm{mg} /$ day). The dose per $\mathrm{kg}$ was nonsignificantly higher in adolescents. Patients with FPLD were treated with higher doses of metreleptin compared to those with GL.

Metreleptin was approved by the FDA in 2014 for treatment of adult and pediatric patients with GL to treat metabolic complications of lipodystrophy, as an adjunct to diet and lifestyle modifications $(90,91)$. Although metreleptin therapy resulted in heterogeneous improvements in patients with PL, in a subset probably consisting of PL patients with low leptin levels, metreleptin is likely to be beneficial $(59,60)$. Although the FDA has not yet approved metreleptin for treatment of PL, the European Medicines Agency's (EMA) Committee for Medicinal Products for Human Use (CHMP) has approved metreleptin in patients with PL in whom standard treatments have failed to achieve adequate metabolic control (92). There is no age limit for treatment in the US, and it has been used in infants as young as six months of age (85). However, the EMA CHMP's recent positive opinion includes authorization for metreleptin only in children two years of age and above with GL, and in children 12 years of age and above with PL (93). In Turkey, metreleptin therapy is currently available only for GL patients for whom standard treatments have failed to control HbA1c and triglyceride levels (94).

The generally recommended starting dose of metreleptin is $5 \mathrm{mg} /$ day in females greater than $40 \mathrm{~kg}, 2.5 \mathrm{mg} /$ day in males greater than $40 \mathrm{~kg}$, and $0.06 \mathrm{mg} / \mathrm{kg} /$ day $(0.012 \mathrm{~mL} / \mathrm{kg})$ in males and females less than or equal to $40 \mathrm{~kg}$ (91). The dose should be kg based in children, and the physicians should keep in mind that most children will require increasing per kg doses, especially as they reach puberty. However, the dose should be adjusted based on clinical response, and tolerability issues should also be borne in mind including excessive weight loss in pediatric patients. Metreleptin can be given once daily at any time of day regardless of meals $(4,5)$. The most common side-effects are hypoglycemia and injection site reactions, such as erythema and/or urticarial (91). Metreleptin therapy has been shown to have beneficial effects on kidney function (95). However, a few patients have been described with worsening of proteinuria on metreleptin (91). This observation needs to be confirmed empirically as the disease progression itself can cause worsening proteinuria.

Two important issues which led to a "black box" warning in the US need to be specifically discussed. These are the development of neutralizing antibody and T-cell lymphoma. Anti-metreleptin antibodies were reported in a considerable number of patients with lipodystrophy on metreleptin. However, antibodies with in vivo neutralizing activity have only been detected in a small number of patients (96). T-cell lymphoma has been reported in a few patients with AGL treated with metreleptin $(97,98)$. Immune dysfunction is a feature of the natural history in patients with AGL $(42,44)$. To date no lymphoma development has been reported in patients with CGL or FPLD treated with metreleptin. Current evidence suggests that lymphoma development in patients with AGL may be associated with the natural history of the disease rather than being a treatment effect associated with metreleptin.

\section{Challenges in the Management of Lipodystrophy in Childhood and Adolescence}

The needs of pediatric patients are different to those of adults and there are several challenges specific to children and young people in the management of lipodystrophy. Crying gives the baby a way to call for help when he/she is hungry or uncomfortable. Babies with lipodystrophy feel hungry all the time because of leptin deficiency. Appetite control is almost impossible in GL especially during active growth without getting help from metreleptin therapy. Even on metreleptin, patients and parents struggle to decide on the right amount of food to consume. Metreleptin causes weight loss in most patients. Parents become stressed when they witness their children losing weight on metreleptin, especially as they already look very thin because of the lipodystrophy.

Small children may have difficulties with verbalizing symptoms, such as abdominal pain caused by acute pancreatitis, symptoms of hyper- or hypoglycemia, muscle symptoms and infections. It may also be difficult to explain to children and adolescents why metabolic control is critical in lipodystrophy. The need for different types of therapies, and tasks such as glucose monitoring, routine blood sampling and regular hospital visits, being careful with what type of food is eaten and how much food is eaten given the associated hyperphagia is overwhelming for many of them. Children with lipodystrophy may need multiple injectable treatments including both insulin and metreleptin. Even though metreleptin therapy may allows the reduction in frequency or even the discontinuation of insulin injections metreleptin is still an injectable agent. In addition the lack of subcutaneous tissue makes the injection technique more challenging in lipodystrophy. It should be also noted that the relatively large injection volume would be another issue with metreleptin injections. It may prove difficult to get an active child to accept injections and self-monitoring of blood glucose at home.

Physical appearance is a big problem for adolescents with lipodystrophy. They may be worried about being with their 
friends and in new social environments. Anger and temper outbursts are common. They may also have specific fears associated with the subtype of lipodystrophy.

To provide timely diagnosis and improve the delivery and quality of care, specialized centers for lipodystrophy for affected children and adolescents should be established. Optimizing management algorithms for children and young people can provide guidance for the use of standard and novel therapies to ensure adequate metabolic control and to prevent complications of lipodystrophy. These centers would develop more experience and thus be able to provide better and more efficient education for patients and their parents about lipodystrophy and its management. This should result in improved adherence to therapies and quality of life for these patients and their families. Cost of treatment remains the biggest barrier to access to novel treatments, such as metreleptin. However, the recent EMA approval of metreleptin therapy is a promising development for lipodystrophy patients in Europe and elsewhere in the world where the recommendations of EMA are adopted by the local authorities. It is important to state that regulatory authority approval does not guarantee access, if local health care coverage programs do not include therapies for rare diseases in their formularies. If metreleptin therapy is not an option in a specific country, or for a patient's plan, access to metreleptin can potentially be established through compassionate use programs and other regulatory mechanisms.

\section{Conclusion}

Lipodystrophy syndromes are a heterogeneous group of disorders, characterized by the lack of adipose tissue, and is associated with severe insulin resistance that usually results in metabolic abnormalities leading to serious morbidity and increased mortality. Although there is no definitive cure for lipodystrophy, patients may benefit from an early diagnosis made in childhood, which in turn may improve lipodystrophy outcomes by providing care at the earliest stage possible. Effective strategies should be developed to overcome challenges in the management of lipodystrophy in children and young people.

\section{Ethics}

Peer-review: Internally peer-reviewed.

\section{Authorship Contributions}

Surgical and Medical Practices: Samim Özen, Barış Akıncı, Elif A. Oral, Concept: Samim Özen, Barış Akıncı, Elif A. Oral, Design: Samim Özen, Barış Akıncı, Elif A. Oral,
Data Collection or Processing: Samim Özen, Barış Akınc1, Analysis or Interpretation: Samim Özen, Barış Akıncı, Literature Search: Samim Özen, Barış Akıncı, Elif A. Oral, Writing: Samim Özen, Barış Akıncı, Elif A. Oral.

Conflict of Interest: No conflict of interest was declared by the authors.

Financial Disclosure: The authors declared that this study received no financial support.

\section{References}

1. Akinci B, Sahinoz M, Oral E. Lipodystrophy Syndromes: Presentation and Treatment. In: Feingold KR, Anawalt B, Boyce A, et al., eds. Endotext. South Dartmouth (MA) 2018. Available from: https://www. ncbi.nlm.nih.gov/pubmed/29989768

2. Chan JL, Oral EA. Clinical classification and treatment of congenital and acquired lipodystrophy. Endocr Pract 2010;16:310-323.

3. Garg A. Clinical review\#: Lipodystrophies: genetic and acquired body fat disorders. J Clin Endocrinol Metab 2011;96:3313-3325. Epub 2011 Aug 24

4. Brown RJ, Araujo-Vilar D, Cheung PT, Dunger D, Garg A, Jack M, Mungai L, Oral EA, Patni N, Rother KI, von Schnurbein J, Sorkina E, Stanley T, Vigouroux C, Wabitsch M, Williams R, Yorifuji T. The Diagnosis and Management of Lipodystrophy Syndromes: A Multi-Society Practice Guideline. J Clin Endocrinol Metab 2016;101:4500-4511 . Epub 2016 Oct 6

5. Handelsman Y, Oral EA, Bloomgarden ZT, Brown RJ, Chan JL, Einhorn D, Garber AJ, Garg A, Garvey WT, Grunberger G, Henry RR, Lavin N, Tapiador CD, Weyer C; American Association of Clinical Endocrinologists. The clinical approach to the detection of lipodystrophy - an AACE consensus statement. Endocr Pract 2013;19:107-116.

6. Gupta N, Asi N, Farah W, Almasri J, Barrionuevo P, Alsawas M, Wang Z, Haymond MW, Brown RJ, Murad MH. Clinical Features and Management of Non-HIV-Related Lipodystrophy in Children: A Systematic Review. J Clin Endocrinol Metab 2017;102:363-374

7. Patni N, Garg A. Congenital generalized lipodystrophies--new insights into metabolic dysfunction. Nat Rev Endocrinol 2015;11:522-534. Epub 2015 Aug 4

8. Garg A. Acquired and inherited lipodystrophies. N Engl J Med 2004;350:1220-1234

9. Chiquette E, Oral EA, Garg A, Araujo-Vilar D, Dhankhar P. Estimating the prevalence of generalized and partial lipodystrophy: findings and challenges. Diabetes Metab Syndr Obes 2017;10:375-383.

10. Akinci B, Onay H, Demir T, Ozen S, Kayserili H, Akinci G, Nur B, Tuysuz B, Nuri Ozbek M, Gungor A, Yildirim Simsir I, Altay C, Demir L, Simsek E, Atmaca M, Topaloglu H, Bilen H, Atmaca H, Atik T, Cavdar U, Altunoglu U, Aslanger A, Mihci E, Secil M, Saygili F, Comlekci A, Garg A. Natural History of Congenital Generalized Lipodystrophy: A Nationwide Study From Turkey. J Clin Endocrinol Metab 2016;101:2759-2767. Epub 2016 May 4.

11. Agarwal AK, Arioglu E, De Almeida S, Akkoc N, Taylor SI, Bowcock AM, Barnes RI, Garg A. AGPAT2 is mutated in congenital generalized lipodystrophy linked to chromosome 9q34. Nat Genet 2002;31:21-23. Epub 2002 Apr 22

12. Cortes VA, Curtis DE, Sukumaran S, Shao X, Parameswara V, Rashid S, Smith AR, Ren J, Esser V, Hammer RE, Agarwal AK, Horton JD, Garg A. Molecular mechanisms of hepatic steatosis and insulin resistance in the AGPAT2-deficient mouse model of congenital generalized lipodystrophy. Cell Metab 2009;9:165-176. 
13. Vatier C, Bidault G, Briand N, Guénantin AC, Teyssières L, Lascols O, Capeau J, Vigouroux C. What the genetics of lipodystrophy can teach us about insulin resistance and diabetes. Curr Diab Rep 2013;13:757767.

14. Simha V, Garg A. Phenotypic heterogeneity in body fat distribution in patients with congenital generalized lipodystrophy caused by mutations in the AGPAT2 or seipin genes. J Clin Endocrinol Metab 2003;88:5433-5437.

15. Altay C, Secil M, Demir T, Atik T, Akıncı G, Özdemir Kutbay N, Keskin Temeloğlu E, Yıldırım Şimşir I, Özışık S, Demir L, Eren E, Tuna EB, Aytaç H, Onay H, Akıncı B. Determining residual adipose tissue characteristics with MRI in patients with various subtypes of lipodystrophy. Diagn Interv Radiol 2017;23:428-434.

16. Magré J, Delépine M, Khallouf E, Gedde-Dahl T Jr, Van Maldergem L, Sobel E, Papp J, Meier M, Mégarbané A, Bachy A, Verloes A, d'Abronzo FH, Seemanova E, Assan R, Baudic N, Bourut C, Czernichow P, Huet F, Grigorescu F, de Kerdanet M, Lacombe D, Labrune P, Lanza M, Loret H, Matsuda F, Navarro J, Nivelon-Chevalier A, Polak M, Robert JJ, Tric P, Tubiana-Rufi N, Vigouroux C, Weissenbach J, Savasta S, Maassen JA, Trygstad O, Bogalho P, Freitas P, Medina JL, Bonnicci F, Joffe BI, Loyson G, Panz VR, Raal FJ, O'Rahilly S, Stephenson T, Kahn CR, Lathrop M, Capeau J; BSCL Working Group. Identification of the gene altered in Berardinelli-Seip congenital lipodystrophy on chromosome 11 q13. Nat Genet 2001;28:365-370.

17. Cartwright BR, Goodman JM. Seipin: from human disease to molecular mechanism. J Lipid Res 2012;53:1042-1055. Epub 2012 Apr 2

18. Lightbourne M, Brown RJ. Genetics of Lipodystrophy. Endocrinol Metab Clin North Am 2017;46:539-554. Epub 2017 Feb 22

19. Kim CA, Delépine M, Boutet E, El Mourabit H, Le Lay S, Meier M, Nemani M, Bridel E, Leite CC, Bertola DR, Semple RK, O'Rahilly S, Dugail I, Capeau J, Lathrop M, Magré J. Association of a homozygous nonsense caveolin-1 mutation with Berardinelli-Seip congenital lipodystrophy. J Clin Endocrinol Metab 2008;93:1129-1134. Epub 2008 Jan 22

20. Cao H, Alston L, Ruschman J, Hegele RA. Heterozygous CAV1 frameshift mutations (MIM 601047) in patients with atypical partial lipodystrophy and hypertriglyceridemia. Lipids Health Dis 2008;7:3.

21. Hayashi YK, Matsuda C, Ogawa M, Goto K, Tominaga K, Mitsuhashi S, Park YE, Nonaka I, Hino-Fukuyo N, Haginoya K, Sugano H, Nishino I. Human PTRF mutations cause secondary deficiency of caveolins resulting in muscular dystrophy with generalized lipodystrophy. J Clin Invest 2009;119:2623-2633. Epub 2009 Aug 10

22. Perez-Diaz S, Johnson LA, DeKroon RM, Moreno-Navarrete JM, Alzate O, Fernandez-Real JM, Maeda N, Arbones-Mainar JM. Polymerase I and transcript release factor (PTRF) regulates adipocyte differentiation and determines adipose tissue expandability. FASEB J 2014;28:3769-3779. Epub 2014 May 8

23. Akinci G, Topaloglu H, Akinci B, Onay H, Karadeniz C, Ergul Y, Demir T, Ozcan EE, Altay C, Atik T, Garg A. Spectrum of clinical manifestations in two young Turkish patients with congenital generalized lipodystrophy type 4. Eur J Med Genet 2016;59:320-324. Epub 2016 May 7

24. Akinci G, Topaloglu H, Demir T, Danyeli AE, Talim B, Keskin FE, Kadioglu P, Talip E, Altay C, Yaylali GF, Bilen H, Nur B, Demir L, Onay H, Akinci B. Clinical spectra of neuromuscular manifestations in patients with lipodystrophy: A multicenter study. Neuromuscul Disord 2017;27:923930. Epub 2017 Jun 1

25. Garg A, Kircher M, Del Campo M, Amato RS, Agarwal AK; University of Washington Center for Mendelian Genomics. Whole exome sequencing identifies de novo heterozygous CAV1 mutations associated with a novel neonatal onset lipodystrophy syndrome. Am J Med Genet A 2015;167:1796-1806. Epub 2015 Apr 21
26. Hussain I, Patni N, Ueda M, Sorkina E, Valerio CM, Cochran E, Brown RJ, Peeden J, Tikhonovich Y, Tiulpakov A, Stender SRS, Klouda E, Tayeh MK, Innis JW, Meyer A, Lal P, Godoy-Matos AF, Teles MG, AdamsHuet B, Rader DJ, Hegele RA, Oral EA, Garg A. A Novel Generalized Lipodystrophy-associated Progeroid Syndrome due to recurrent heterozygous LMNA p.T10I Mutation. J Clin Endocrinol Metab 2018;103:1005-1014.

27. Dyment DA, Gibson WT, Huang L, Bassyouni H, Hegele RA, Innes AM. Biallelic mutations at PPARG cause a congenital, generalized lipodystrophy similar to the Berardinelli-Seip syndrome. Eur J Med Genet 2014;57:524-526. Epub 2014 Jun 28

28. Payne F, Lim K, Girousse A, Brown RJ, Kory N, Robbins A, Xue Y, Sleigh A, Cochran E, Adams C, Dev Borman A, Russel-Jones D, Gorden P, Semple RK, Saudek V, O'Rahilly S, Walther TC, Barroso I, Savage DB. Mutations disrupting the Kennedy phosphatidylcholine pathway in humans with congenital lipodystrophy and fatty liver disease. Proc Natl Acad Sci U S A 2014;111:8901-8906. Epub 2014 Jun 2

29. Chan D, McIntyre AD, Hegele RA, Don-Wauchope AC. Familial partial lipodystrophy presenting as metabolic syndrome. J Clin Lipidol 2016;10:1488-1491. Epub 2016 Sep 1

30. Akinci B, Onay H, Demir T, Savas-Erdeve Ş, Gen R, Simsir IY, Keskin FE, Erturk MS, Uzum AK, Yaylali GF, Ozdemir NK, Atik T, Ozen S, Yurekli BS, Apaydin T, Altay C, Akinci G, Demir L, Comlekci A, Secil M, Oral EA. Clinical presentations, metabolic abnormalities and endorgan complications in patients with familial partial lipodystrophy. Metabolism 2017;72:109-119. Epub 2017 Apr 27

31. Ajluni N, Meral R, Neidert AH, Brady GF, Buras E, McKenna B, DiPaola F, Chenevert TL, Horowitz JF, Buggs-Saxton C, Rupani AR, Thomas PE, Tayeh MK, Innis JW, Omary MB, Conjeevaram H, Oral EA. Spectrum of disease associated with partial lipodystrophy: lessons from a trial cohort. Clin Endocrinol (Oxf) 2017;86:698-707. Epub 2017 Mar 27

32. Haque WA, Oral EA, Dietz K, Bowcock AM, Agarwal AK, Garg A. Risk factors for diabetes in familial partial lipodystrophy, Dunnigan variety. Diabetes Care 2003;26:1350-1355.

33. Lotta LA, Gulati P, Day FR, Payne F, Ongen H, van de Bunt M, Gaulton KJ, Eicher JD, Sharp SJ, Luan J, De Lucia Rolfe E, Stewart ID, Wheeler E, Willems SM, Adams C, Yaghootkar H; EPIC-InterAct Consortium; Cambridge FPLD1 Consortium, Forouhi NG, Khaw KT, Johnson AD, Semple RK, Frayling T, Perry JR, Dermitzakis E, McCarthy MI, Barroso I, Wareham NJ, Savage DB, Langenberg C, O'Rahilly S, Scott RA. Integrative genomic analysis implicates limited peripheral adipose storage capacity in the pathogenesis of human insulin resistance. Nat Genet 2017;49:17-26. Epub 2016 Nov 14

34. Guillin-Amarelle C, Sanchez-Iglesias S, Castro-Pais A, Rodriguez-Cañete L, Ordóñez-Mayán L, Pazos M, González-Méndez B, Rodríguez-García S, Casanueva FF, Fernández-Marmiesse A, Araújo-Vilar D. Type 1 familial partial lipodystrophy: understanding the Kobberling syndrome. Endocrine 2016;54:411-421. Epub 2016 Jul 30

35. Herbst KL, Tannock LR, Deeb SS, Purnell JQ, Brunzell JD, Chait A. Köbberling type of familial partial lipodystrophy: an underrecognized syndrome. Diabetes Care 2003;26:1819-1824.

36. Shackleton S, Lloyd DJ, Jackson SN, Evans R, Niermeijer MF, Singh BM, Schmidt H, Brabant G, Kumar S, Durrington PN, Gregory S, O’Rahilly $\mathrm{S}$, Trembath RC. LMNA, encoding lamin A/C, is mutated in partial lipodystrophy. Nat Genet 2000;24:153-156.

37. Araujo-Vilar D, Victoria B, Gonzalez-Mendez B, Barreiro F, FernándezRodriguez B, Cereijo R, Gallego-Escuredo JM, Villarroya F, PañedaMenéndez A. Histological and molecular features of lipomatous and nonlipomatous adipose tissue in familial partial lipodystrophy caused by LMNA mutations. Clin Endocrinol (Oxf) 2012;76:816-824. 
38. Hegele RA, Cao H, Huff MW, Anderson CM. LMNA R482Q mutation in partial lipodystrophy associated with reduced plasma leptin concentration. J Clin Endocrinol Metab 2000;85:3089-3093.

39. Jeru I, Vatier C, Araujo-Vilar D, Vigouroux C, Lascols O. Clinical Utility Gene Card for: Familial partial lipodystrophy. Eur J Hum Genet 2017:25. Epub 2016 Aug 3

40. Barroso I, Gurnell M, Crowley VE, Agostini M, Schwabe JW, Soos MA, Maslen GL, Williams TD, Lewis H, Schafer AJ, Chatterjee VK, O’Rahilly $\mathrm{S}$. Dominant negative mutations in human PPARgamma associated with severe insulin resistance, diabetes mellitus and hypertension. Nature 1999;402:880-883.

41. Agarwal AK, Garg A. A novel heterozygous mutation in peroxisome proliferator-activated receptor-gamma gene in a patient with familial partial lipodystrophy. J Clin Endocrinol Metab 2002;87:408-411.

42. Misra A, Garg A. Clinical features and metabolic derangements in acquired generalized lipodystrophy: case reports and review of the literature. Medicine (Baltimore) 2003;82:129-146.

43. Garg A, Misra A. Lipodystrophies: rare disorders causing metabolic syndrome. Endocrinol Metab Clin North Am 2004;33:305-331.

44. Misra A, Peethambaram A, Garg A. Clinical features and metabolic and autoimmune derangements in acquired partial lipodystrophy: report of 35 cases and review of the literature. Medicine (Baltimore) 2004;83:1834.

45. Yavuz S, Acartürk TO. Acquired partial lipodystrophy with C3 hypocomplementemia and antiphospholipid and anticardiolipin antibodies. Pediatr Dermatol 2010;27:504-508.

46. Akinci B, Koseoglu FD, Onay H, Yavuz S, Altay C, Simsir IY, Ozisik S, Demir L, Korkut M, Yilmaz N, Ozen S, Akinci G, Atik T, Calan M, Secil M, Comlekci A, Demir T. Acquired partial lipodystrophy is associated with increased risk for developing metabolic abnormalities. Metabolism 2015;64:1086-1095. Epub 2015 Jun 10

47. Donadille B, D’Anella P, Auclair M, Uhrhammer N, Sorel M, Grigorescu R, Ouzounian S, Cambonie G, Boulot P, Laforêt P, Carbonne B, ChristinMaitre S, Bignon YJ, Vigouroux C. Partial lipodystrophy with severe insulin resistance and adult progeria Werner syndrome. Orphanet J Rare Dis 2013;8:106.

48. Cabanillas R, Cadinanos J, Villameytide JA, Pérez M, Longo J, Richard JM, Alvarez R, Durán NS, Illán R, González DJ, López-Otín C. NestorGuillermo progeria syndrome: a novel premature aging condition with early onset and chronic development caused by BANF1 mutations. Am J Med Genet A 2011;155:2617-2625. Epub 2011 Sep 19

49. Wei C, Thyagiarajan MS, Hunt LP, Shield JP, Stevens MC, Crowne EC. Reduced insulin sensitivity in childhood survivors of haematopoietic stem cell transplantation is associated with lipodystropic and sarcopenic phenotypes. Pediatr Blood Cancer 2015;62:1992-1999. Epub 2015 May 19

50. Ceccarini G, Ferrari F, Santini F. Acquired partial lipodystrophy after bone marrow transplant during childhood: a novel syndrome to be added to the disease classification list. J Endocrinol Invest 2017;40:1273-1274. Epub 2017 Jul 18

51. Rooney DP, Ryan MF. Diabetes with partial lipodystrophy following sclerodermatous chronic graft vs. host disease. Diabet Med 2006;23:436-440.

52. Adachi M, Asakura Y, Muroya K, Goto H, Kigasawa H. Abnormal adipose tissue distribution with unfavorable metabolic profile in five children following hematopoietic stem cell transplantation: a new etiology for acquired partial lipodystrophy. Clin Pediatr Endocrinol 2013;22:53-64. Epub 2013 Oct 26

53. Adachi M, Oto Y, Muroya K, Hanakawa J, Asakura Y, Goto H. Partial lipodystrophy in patients who have undergone hematopoietic stem cell transplantation during childhood: an institutional cross- sectional survey. Clin Pediatr Endocrinol 2017;26:99-108. Epub 2017 Apr 22

54. Hosokawa M, Shibata H, Hosokawa T, Irie J, Ito H, Hasegawa T. Acquired partial lipodystrophy with metabolic disease in children following hematopoietic stem cell transplantation: a report of two cases and a review of the literature. J Pediatr Endocrinol Metab 2019;32:537-541.

55. Patni N, Alves C, von Schnurbein J, Wabitsch M, Tannin G, Rakheja D, Garg A. A Novel Syndrome of Generalized Lipodystrophy Associated With Pilocytic Astrocytoma. J Clin Endocrinol Metab 2015;100:36033606. Epub 2015 Aug 7

56. Le Coz C, Nolan BE, Trofa M, Kamsheh AM, Khokha MK, Lakhani SA, Novelli A, Zackai EH, Sullivan KE, Briuglia S, Bhatti TR, Romberg N. Cytotoxic T-Lymphocyte-Associated Protein 4 HaploinsufficiencyAssociated Inflammation Can Occur Independently of T-Cell Hyperproliferation. Front Immunol 2018;9:1715.

57. Falcao CK, Cabral MCS, Mota JM, Arbache ST, Costa-Riquetto AD, Muniz DQB, Cury-Martins J, Almeida MQ, Kaczemorska PC, Nery M, Teles MG. Acquired Lipodystrophy Associated With Nivolumab in a Patient With Advanced Renal Cell Carcinoma. J Clin Endocrinol Metab 2019;104:3245-3248.

58. Haque WA, Shimomura I, Matsuzawa Y, Garg A. Serum adiponectin and leptin levels in patients with lipodystrophies. J Clin Endocrinol Metab 2002;87:2395.

59. Ajluni N, Dar M, Xu J, Neidert AH, Oral EA. Efficacy and Safety of Metreleptin in Patients with Partial Lipodystrophy: Lessons from an Expanded Access Program. J Diabetes Metab 2016:7. Epub 2016 Mar 23

60. Diker-Cohen T, Cochran E, Gorden P, Brown RJ. Partial and generalized lipodystrophy: comparison of baseline characteristics and response to metreleptin. J Clin Endocrinol Metab 2015;100:1802-1810. Epub 2015 Mar 3

61. Kennedy A, Gettys TW, Watson P, Wallace P, Ganaway E, Pan Q, Garvey WT. The metabolic significance of leptin in humans: gender-based differences in relationship to adiposity, insulin sensitivity, and energy expenditure. J Clin Endocrinol Metab 1997;82:1293-1300

62. Clayton PE, Gill MS, Hall CM, Tillmann V, Whatmore AJ, Price DA. Serum leptin through childhood and adolescence. Clin Endocrinol (Oxf) 1997;46:727-733

63. Erhardt E, Foraita R, Pigeot I, Barba G, Veidebaum T, Tornaritis M, Michels N, Eiben G, Ahrens W, Moreno LA, Kovács E, Molnár D; IDEFICS consortium. Reference values for leptin and adiponectin in children below the age of 10 based on the IDEFICS cohort. Int J Obes (Lond) 2014;38(Suppl 2):32-38.

64. Kirel B, Doğruel N, Akgün N, Kiliç FS, Tekin N, Uçar B. Serum leptin levels during childhood and adolescence: relationship with age, sex, adiposity and puberty. Turk J Pediatr 1999;41:447-455.

65. Bronsky J, Mitrova K, Karpisek M, Mazoch J, Durilova M, Fisarkova B, Stechova K, Prusa R, Nevoral J. Adiponectin, AFABP, and leptin in human breast milk during 12 months of lactation. J Pediatr Gastroenterol Nutr 2011;52:474-477.

66. Savino F, Rossi L, Benetti S, Petrucci E, Sorrenti M, Silvestro L. Serum reference values for leptin in healthy infants. PLoS One 2014;9:e113024.

67. Alexe DM, Syridou G, Petridou ET. Determinants of early life leptin levels and later life degenerative outcomes. Clin Med Res 2006;4:326335.

68. Antuna-Puente B, Boutet E, Vigouroux C, Lascols O, Slama L, CaronDebarle M, Khallouf E, Lévy-Marchal C, Capeau J, Bastard JP, Magré J. Higher Adiponectin Levels in Patients with Berardinelli-Seip Congenital Lipodystrophy due to Seipin as compared with 1-Acylglycerol-3Phosphate-O-Acyltransferase-2 Deficiency. J Clin Endocrinol Metab 2010;95:1463-1468. Epub 2010 Jan 22 
69. Akinci B, Unlu SM, Celik A, Simsir IY, Sen S, Nur B, Keskin FE, Ozgen Saydam B, Kutbay Ozdemir N, Sarer Yurekli B, Ergur BU, Sonmez M, Atik T, Arslan A, Demir T, Altay C, Tunc UA, Arkan T, Gen R, Eren E, Akinci G, Yilmaz AA, Bilen H, Ozen S, Celtik A, Savas Erdeve S, Cetinkaya S, Onay H, Sarioglu S, Oral EA. Renal complications of lipodystrophy: A closer look at the natural history of kidney disease. Clin Endocrinol (Oxf) 2018;89:65-75. Epub 2018 May 17

70. Moran SA, Gorden P, O'Rahilly S, Zaidi Z, Gurakan F, Arslanian SA, Klar A, Ricker A, White NH, Bindl L, Herbst K, Kennel K, Patel SB, AlGazali L, Garg A. Phenotypic and genetic heterogeneity in congenital generalized lipodystrophy. J Clin Endocrinol Metab 2003;88:48404847

71. Garg A, Vinaitheerthan M, Weatherall PT, Bowcock AM. Phenotypic heterogeneity in patients with familial partial lipodystrophy (dunnigan variety) related to the site of missense mutations in lamin a/c gene. J Clin Endocrinol Metab 2001;86:59-65.

72. de Azevedo Medeiros LB, Candido Dantas VK, Craveiro Sarmento AS, Agnez-Lima LF, Meireles AL, Xavier Nobre TT, de Lima JG, de Melo Campos JTA. High prevalence of Berardinelli-Seip Congenital Lipodystrophy in Rio Grande do Norte State, Northeast Brazil. Diabetol Metab Syndr 2017;9:80.

73. Lima JG, Nobrega LHC, Lima NN, Dos Santos MCF, Silva PHD, Baracho MFP, Lima DN, de Melo Campos JTA, Ferreira LC, Freire Neto FP, Mendes-Aguiar CO, Jeronimo SMB. Causes of death in patients with Berardinelli-Seip congenital generalized lipodystrophy. PLoS One 2018;13:e0199052.

74. Haghighi A, Kavehmanesh Z, Haghighi A, Salehzadeh F, SantosSimarro F, Van Maldergem L, Cimbalistiene L, Collins F, Chopra M, AlSinani S, Dastmalchian S, de Silva DC, Bakhti H, Garg A, Hilbert P. Congenital generalized lipodystrophy: identification of novel variants and expansion of clinical spectrum. Clin Genet 2016;89:434-441. Epub 2015 Jul 20

75. Musso C, Cochran E, Javor E, Young J, Depaoli AM, Gorden P. The long-term effect of recombinant methionyl human leptin therapy on hyperandrogenism and menstrual function in female and pituitary function in male and female hypoleptinemic lipodystrophic patients. Metabolism 2005;54:255-263.

76. Shah AS, Wilson DP. Primary hypertriglyceridemia in children and adolescents. J Clin Lipidol 2015;9(5 Suppl):20-28. Epub 2015 Apr 25

77. Manlhiot C, Larsson P, Gurofsky RC, Smith RW, Fillingham C, Clarizia NA, Chahal N, Clarke JT, McCrindle BW. Spectrum and management of hypertriglyceridemia among children in clinical practice. Pediatrics 2009;123:458-465.

78. Food and Drug Administration. Avaliable from: https://www.accessdata.fda. gov/drugsatfda_docs/label/2017/020357s037s039,021202s021 s023lbl. pdf

79. Oral EA, Chan JL. Rationale for leptin-replacement therapy for severe lipodystrophy. Endocr Pract 2010;16:324-333.

80. McDuffie JR, Riggs PA, Calis KA, Freedman RJ, Oral EA, DePaoli AM, Yanovski JA. Effects of exogenous leptin on satiety and satiation in patients with lipodystrophy and leptin insufficiency. J Clin Endocrinol Metab 2004;89:4258-4263.

81. Oral EA, Simha V, Ruiz E, Andewelt A, Premkumar A, Snell P, Wagner AJ, DePaoli AM, Reitman ML, Taylor SI, Gorden P, Garg A. Leptinreplacement therapy for lipodystrophy. N Engl J Med 2002;346:570578.

82. Brown RJ, Oral EA, Cochran E, Araújo-Vilar D, Savage DB, Long A, Fine G, Salinardi T, Gorden P. Long-term effectiveness and safety of metreleptin in the treatment of patients with generalized lipodystrophy. Endocrine 2018;60:479-489. Epub 2018 Apr 12

83. Chan JL, Lutz K, Cochran E, Huang W, Peters Y, Weyer C, Gorden P. Clinical effects of long-term metreleptin treatment in patients with lipodystrophy. Endocr Pract 2011;17:922-932.

84. Oral EA, Javor ED, Ding L, Uzel G, Cochran EK, Young JR, DePaoli AM, Holland SM, Gorden P. Leptin replacement therapy modulates circulating lymphocyte subsets and cytokine responsiveness in severe lipodystrophy. J Clin Endocrinol Metab 2006;91:621-628. Epub 2005 Nov 29

85. Brown RJ, Meehan CA, Cochran E, Rother KI, Kleiner DE, Walter M, Gorden P. Effects of Metreleptin in Pediatric Patients With Lipodystrophy. J Clin Endocrinol Metab 2017;102:1511-1519.

86. Brown RJ, Valencia A, Startzell M, Cochran E, Walter PJ, Garraffo HM, Cai H, Gharib AM, Ouwerkerk R, Courville AB, Bernstein S, Brychta RJ, Chen KY, Walter M, Auh S, Gorden P. Metreleptin-mediated improvements in insulin sensitivity are independent of food intake in humans with lipodystrophy. J Clin Invest 2018;128:3504-3516. Epub 2018 Jul 16

87. Simsir IY, Yurekli BS, Saygili F, Altay C, Akinci B. First metreleptin treatment for generalized lipodystrophy in Turkey. Diabetes Obes Metab 2017;19:299-301. Epub 2016 Nov 9

88. Javor ED, Ghany MG, Cochran EK, Oral EA, DePaoli AM, Premkumar A, Kleiner DE, Gorden P. Leptin reverses nonalcoholic steatohepatitis in patients with severe lipodystrophy. Hepatology 2005;41:753-760.

89. Oral EA, Ruiz E, Andewelt A, Sebring N, Wagner AJ, Depaoli AM, Gorden P. Effect of leptin replacement on pituitary hormone regulation in patients with severe lipodystrophy. J Clin Endocrinol Metab 2002;87:3110-3117.

90. Chou K, Perry CM. Metreleptin: first global approval. Drugs 2013;73:989-997.

91. Food and Drug Administration. Available from: https://www.accessdata. fda.gov/drugsatfda_docs/label/2014/125390s000lbl.pdf

92. GlobeNewswire. Available from: https://globenewswire.com/newsrelease/2018/06/01/1515454/0/en/MYALEPTA-metreleptin-ReceivesPositive-CHMP-Opinion-in-Patients-with-Generalized-and-PartialLipodystrophy.html

93. European Medicine Agency. Available from: http://www.ema.europa. eu/docs/en_GB/document_library/Summary_of_opinion_-_Initial_ authorisation/human/004218/WC500249804.pdf

94. T.C. Sağlık Bakanlığı. Türkiye İlaç ve Tibbi Cihaz Kurumu. Available from: https://www.titck.gov.tr

95. Javor ED, Moran SA, Young JR, Cochran EK, DePaoli AM, Oral EA, Turman MA, Blackett PR, Savage DB, O'Rahilly S, Balow JE, Gorden P. Proteinuric nephropathy in acquired and congenital generalized lipodystrophy: baseline characteristics and course during recombinant leptin therapy. J Clin Endocrinol Metab 2004;89:3199-3207.

96. Chan JL, Koda J, Heilig JS, Cochran EK, Gorden P, Oral EA, Brown RJ. Immunogenicity associated with metreleptin treatment in patients with obesity or lipodystrophy. Clin Endocrinol (Oxf) 2016;85:137-149. Epub 2016 Feb 2

97. Brown RJ, Chan JL, Jaffe ES, Cochran E, DePaoli AM, Gautier JF, Goujard C, Vigouroux C, Gorden P. Lymphoma in acquired generalized lipodystrophy. Leuk Lymphoma 2016;57:45-50. Epub 2015 May 12

98. Aslam A, Savage DB, Coulson IH. Acquired generalized lipodystrophy associated with peripheral $\mathrm{T}$ cell lymphoma with cutaneous infiltration. Int J Dermatol 2015;54:827-829. Epub 2013 Oct 29 